\title{
The Effect Of Consolidation On Employees In The U.S. Banking Industry
}

Joseph N. Heiney, Elmhurst College, USA

\begin{abstract}
This paper examines the effect of the continuing consolidation on employees in the U.S. banking industry between 1992 and 2004. It documents the decreasing number of banking institutions, the number of employees, and level of salaries and benefits. The data indicates that while the number of banks has continued to decrease, the levels of employment and compensation have, in fact, increased during this period.
\end{abstract}

Keywords: Banking, consolidation, employment, compensation

\section{INTRODUCTION}

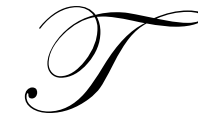

industry.

he McFadden Act of 1927 restricted interstate banking and branching in the U.S. The Riegle-Neal Banking and Branching Efficiency Act of 1994 removed these restrictions. This was expected to accelerate the trend toward consolidation which was already taking place in the U.S. banking

In previous research, Matasar and Heiney (2002) studied the immediate effects of the deregulation instituted by Riegle Neal. Since Riegle-Neal was passed in 1994 and became fully effective in 1997, Matasar and Heiney examined data from 1990 to 1998 to capture the initial impact of the act by looking at the period from before the act was passed to immediately after the act became fully effective. This paper examines the changes in the level of employment and compensation in the U.S. banking industry during the continuing consolidation since RiegleNeal became fully effective. It presents information on the changes in employment and compensation in the U.S. banking industry to determine whether or not the trends observed in the immediate aftermath of Riegle-Neal have continued.

\section{THE CAUSES AND CONSEQUENCES OF CONSOLIDATION IN THE BANKING INDUSTRY}

Heiney (2008) examined consolidation and asset size distribution in the U.S. banking industry. That paper presented the following discussion of the causes and consequences of consolication. When Riegle-Neal eliminated the restrictions on interstate banking and branching activity, it was expected that newly available merger and acquisition opportunities across state lines would accelerate the consolidation among U.S. banks already underway. There were concerns regarding the resulting impact on the level of bank services and fees and on employment in the industry. Rose (1997) presents a thorough examination of the possible consequences of the increased consolidation resulting from increased interstate banking.

One reason to expect increased merger activity was the opportunity to take advantage of economies of scale. A merger can be a less costly way to achieve efficient asset size than internal expansion. Calem (1994) indicates that there are economies of scale in the banking industry up to an asset size of $\$ 75$ million. Economies of scale seem to run out for banks with assets between $\$ 75$ and $\$ 300$ million. Beyond $\$ 300$ million in assets, diseconomies of scale seem to set in.

Merger activity may also be a mechanism to replace inefficient management. Calomiris and Karceski (1998) ask, "Is the Bank Merger Wave of the 1990s Efficient?" The economic analysis of government regulation often argues that regulation has the effect of protecting less efficient firms from competition by more efficient firms. 
Economides, Hubbard, and Palia (1996) present a political economy model in which it is argued that federal branching restrictions were designed to protect smaller, less efficient banks from larger, more efficient banks. Jayaratne and Strahan (1998) also examine the relationship between entry restrictions and efficiency for commercial banks.

It can also be argued that the interstate mergers newly allowed by Riegle-Neal provided an opportunity for banks to reduce risk through geographic diversification. The extent to which geographic diversification reduces risk for an institution depends on the correlation of economic conditions in different areas of the country. If economic conditions are very highly positively correlated across regions of the country, then geographic expansion through interstate banking and branching will not contribute significantly to the objective of risk reduction. Carlino and Sill (2000) find that the correlation coefficients for real per capita personal income across the regions of the U.S. are typically above 0.88 . The far west region is an exception for which correlation coefficients with the other seven regions are between 0.20 and 0.32 . Sherwood-Cali (1990) examines the economic stability of different regions of the country in terms of state industry diversification. She finds that the reduction of volatility due to industry diversification provides the opportunity of risk reduction through geographic expansion of financial institutions.

Smoluk, Andrews, and Voyer (2003) provide a methodology for examining the "potential benefits of risk reduction for financial institutions wishing to grow primarily through a strategy of geographic expansion." (p. 47) They find that "by strategically investing in different regions, a financial institution could reduce its potential earnings risk by over 58 percent while maintaining or improving potential profitability." (p. 48)

\section{CONSOLIDATION IN THE U.S. BANKING INDUSTRY}

The U.S. has a large number of banks relative to other western industrialized countries, even on a per capita basis or relative to GDP. The number of institutions in the U.S. banking industry held relatively constant at around 14,000 from 1935 to 1985 . Just after this period the number of U.S. banks began a significant decline to under 8,000 in recent years. This decrease in the number of banks began with an unusually large number of bank failures in the mid 1980s. More recently, however, this continuing decrease in the number of U.S. banks has been largely due to mergers and acquisitions.

Consider this more recent period beginning in 1992. Table 1 presents information on the number of commercial banks and the percentage changes in the number of commercial banks from 1993 to 2004. The number of banking institutions decreased from 11,463 to 8,774 between 1992 and 1998. The number of banking institutions was decreasing at a rate of over 4\% per year during this period. Between 1999 and 2004 the number of banking institutions decreased from 8,580 to 7,630. In percentage terms, this represents a rate of decrease of only about $1.5 \%$ to just over $3 \%$ per year. It appears that the rate of consolidation has slowed since the Riegle-Neal Act became fully effective.

Table 1

Number of Banks and Percent Change Number of Banks

\begin{tabular}{|c|c|c|}
\hline Year & Number of Banks & Percent Change Number of Banks \\
\hline 1992 & 11,463 & -4.397 \\
\hline 1993 & 10,959 & -4.626 \\
\hline 1994 & 10,452 & -4.889 \\
\hline 1995 & 9,941 & -4.154 \\
\hline 1996 & 9,528 & -4.041 \\
\hline 1997 & 9,143 & -4.036 \\
\hline 1998 & 8,774 & -2.221 \\
\hline 1999 & 8,580 & -3.089 \\
\hline 2000 & 8,315 & -2.826 \\
\hline 2001 & 8,080 & -2.376 \\
\hline 2001 & 7,888 & -1.496 \\
\hline 2003 & 7,770 & -1.802 \\
\hline
\end{tabular}

Source: FDIC, Statistics on Banking 


\section{CONSOLIDATION AND EMPLOYMENT IN THE U.S. BANKING INDUSTRY}

Among the concerns regarding the acceleration of consolidation in the U.S. banking industry which occurred since the mid 1980s was the affect of consolidation on the level of employment in the banking industry. With respect to the potential impact of consolidation on employment, Rose (1997) noted the concern that "(a)s the number of banks continues to fall, many bankers foresee a continuing shrinkage in the number of bank employees, especially with continuing advances in information and service delivery technology, which tend to expand the role of capital equipment, making those employees who do remain more productive.” (Rose, 1997, p. 74)

In their previous research on the initial impact of Riegle-Neal, Matasar and Heiney (2002) found that between 1996 and 1999, “(a)lthough the number of banking institutions decreased nationwide during this period by almost $10 \%$, the number of full-time equivalent employees increased by almost $15 \%$. This inverse relationship clearly demonstrates that consolidation in the banking industry immediately after passage of Riegle-Neal did not adversely effect employment in the industry nationwide." (Matasar and Heiney, 2002, p. 52)

Table 2 indicates the number of employees and the percent change in the number of bank employees from 1993 to 2004 . For the U.S. banking industry as a whole, these data reveal that while the number of banking institutions decreased consistently during this period, the number of employees increased each year except for 1994 and 1995. For the period from 1999 to 2004 the number of employees in the U.S. banking industry has increased each year by up to $3.124 \%$ in 2004 . (Heiney, 2008)

Table 2

Number of Employees and Percent Change Number of Employees

\begin{tabular}{|c|c|c|}
\hline Year & Number of Employees & Percent Change Number of Employees \\
\hline 1992 & $1,478,373$ & 1.057 \\
\hline 1993 & $1,494,006$ & -0.284 \\
\hline 1994 & $1,489,763$ & -0.307 \\
\hline 1995 & $1,485,185$ & 0.345 \\
\hline 1996 & $1,490,306$ & 3.310 \\
\hline 1997 & $1,539,634$ & 5.676 \\
\hline 1998 & $1,627,018$ & 1.881 \\
\hline 1999 & $1,657,628$ & 0.792 \\
\hline 2000 & $1,670,758$ & 1.853 \\
\hline 2001 & $1,701,721$ & 2.579 \\
\hline 2002 & $1,745,614$ & 0.796 \\
\hline 2003 & $1,759,517$ & 3.124 \\
\hline 2004 & $1,814,491$ & \\
\hline
\end{tabular}

Source: FDIC, Statistics on Banking

\section{CONSOLIDATION AND COMPENSATION IN THE U.S. BANKING INDUSTRY}

While these data indicate that employment in the U.S. banking industry was increasing during this period of continuing consolidation, they do not fully address the effect on employees which depends also on their compensation. It could be that the increase in employment was accompanied by decreasing compensation.

Matasar and Heiney (2002) found that for the period from immediately before to immediately after RiegleNeal became fully effective, i.e., 1996 to 1999, "(a)lthough the number of banks decreased by $10 \%$ and banking employment rose by almost $15 \%$, the level of salary and compensation in the banking industry nationwide increased by almost 30\%." (Matasar and Heiney, 2002, p. 56) This is an average of approximately $7.25 \%$ annually over that four year period. During that four year period inflation averaged $2.4 \%$ annually. Therefore, employees in the U.S. banking industry were, as a group, better off in real terms. 
It would be possible to have increasing employment and increasing compensation at the industry level and still find individual employees worse off if employment were increasing more rapidly than compensation so that compensation per employee was decreasing. However, since for the period 1996 to 1999 employment increased by almost $15 \%$ and compensation increased by almost $30 \%$, it is clear that average compensation for the individual employee increased.

Table 3 presents compensation, i.e., salaries and employee benefits for the U.S. banking industry for the years 1992 to 2006 . The data indicate that from 2000 to 2006 compensation for the industry nationally increased by $50.5 \%$. Relative to the increase in the number of employees in the industry for this period, Table Three indicates that the compensation per employee increased by approximately $28.6 \%$.

Table 3

Salaries and Benefits and Compensation per Employee

\begin{tabular}{|c|c|c|}
\hline Year & Salaries and Benefits in 000s of dollars & Compensation per Employee \\
\hline 1992 & $54,818,778$ & 37,080 \\
\hline 1993 & $58,203,405$ & 38,958 \\
\hline 1994 & $60,623,346$ & 40,693 \\
\hline 1995 & $63,460,904$ & 42,729 \\
\hline 1996 & $67,072,102$ & 45,006 \\
\hline 1997 & $71,812,946$ & 46,643 \\
\hline 1998 & $79,146,029$ & 48,645 \\
\hline 1999 & $85,458,945$ & 51,555 \\
\hline 2000 & $88,572,813$ & 53,014 \\
\hline 2001 & $92,608,342$ & 54,420 \\
\hline 2002 & $100,379,229$ & 57,504 \\
\hline 2003 & $107,802,219$ & 61,268 \\
\hline 2004 & $110,826,027$ & 61,061 \\
\hline 2005 & $122,831,917$ & 65,750 \\
\hline 2006 & $133,313,002$ & 68,162 \\
\hline
\end{tabular}

Source: FDIC, Statistics on Banking

Therefore, it appears that employment and compensation continue to increase during this on-going period of consolidation in the U.S. banking industry.

\section{CONCLUSION}

This paper has extended previous research which studied the initial impact of the Riegle-Neal Act on consolidation, employment, and compensation in the U.S. banking industry by examining the period of time since this deregulation became fully effective to see if the immediate effects set in motion by the passage of the act have continued or moderated.

The data on the number of banking institutions indicate that the number of institutions continues to decrease. However, the rate at which the number of banks is decreasing has slowed since Riegle-Neal became fully effective.

Interestingly, while the number of banking institutions continues to decrease overall, the level of employment in the banking industry continues to increase. It is likely that the increased employment is related to the significant increase in the number of bank branches which has occurred as the number of banking institutions decreases.

Furthermore, compensation per employee in the U.S. banking industry continues to increase. 


\section{AUTHOR INFORMATION}

Joseph N. Heiney is Professor of Economics in the Center for Business and Economics at Elmhurst College, where he was previously the Coleman Foundation Distinguished Chair in Business. He holds the Ph.D. in Economics from the University of Chicago. Dr. Heiney's recent research has been concerned with the impact of consolidation in the U.S. banking industry on profitability, asset size distribution, employment, and compensation. This research has especially concentrated on the period after the passage of the Riegle-Neal Act of 1994.

\section{REFERENCES}

1. Calem, Paul S. "The Impact of Geographic Deregulation on Small Banks," Business Review, (Federal Reserve Bank of Philadelphia), (November - December, 1994), pp. 17 - 31.

2. Calomiris, Charles W. and Jason Karceski. Is the Bank Merger Wave of the 1990's Efficient? Washington, D.C.: The AEI Press, 1998.

3. Carlino, Gerald A. and Keith Sill. "Regional Income Fluctuations: Common Trends and Common Cycles," Federal Reserve Bank of Philadelphia, Working Paper No. 00-8, August, 2000.

4. $\quad$ Economides, Nicholas, R. Glen Hubbard, and Darius Palia. "The Political Economy of Branching Restrictions and Deposit Insurance: A Model of Monopolistic Competition among Small and Large Banks," The Journal of Law and Economics, XXXIX N. 2 (October, 1996), pp. 667-704.

5. $\quad$ FDIC, Statistics on Banking, Historical Statistics on Banking, FDIC web site.

6. Heiney, Joseph N. "Consolidation, Asset Size Distribution, and Employment in the U.S. Banking Industry," Journal of Business and Economics Research, Volume 6, Number 1 (January 2008), pp. 75 - 78.

7. Jayaratne, Jith and Philip E. Strahan. "Entry Restrictions, Industry Evolution, and Dynamic Efficiency: Evidence From Commercial Banking.” Journal of Law and Economics, XLI (April, 1998), pp. 239 - 273.

8. Matasar, Ann B. and Joseph N. Heiney. The Impact of Geographic Deregulation on the American Banking Industry. Westport, Conn.: Quorum Books, 2002.

9. $\quad$ Rose, Peter. Banking Across State Lines: Public and Private Consequences. Westport, Conn.: Quorum Books, 1997.

10. Sherwood-Call, Carolyn. "Assessing Regional Economic Stability: A Portfolio Approach," Economic Review, Federal Reserve Bank of San Francisco, Winter, 1990, pp. 17-26.

11. Smoluk, H. J., Bruce Andrews, and John Voyer. "A Methodology for Analyzing the Effects of Geographic Diversification for Financial Institutions," American Business Review, XXI N. 1 (January, 2003), pp. 47-55. 


\section{NOTES}

